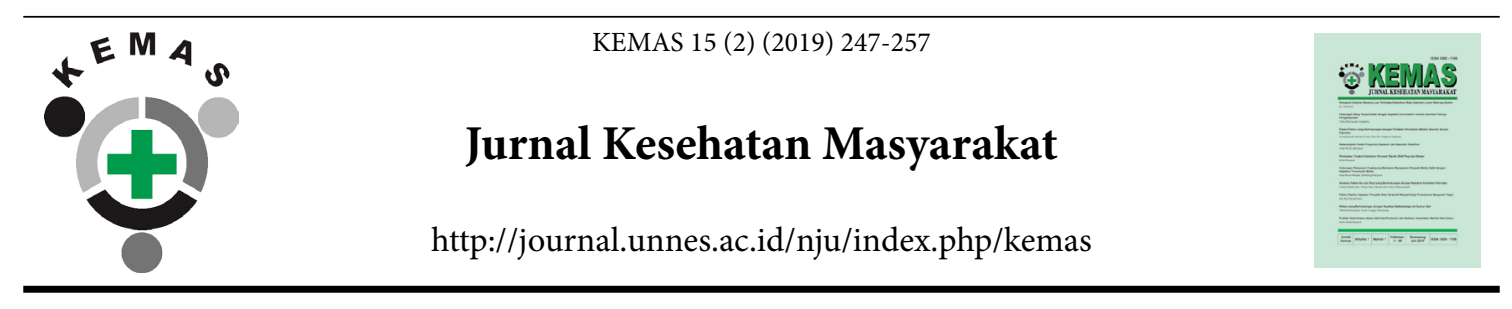

\title{
White Onion (Allium sativum) Extract as a Vegetable Larvicide in Blowfly (Calliphoridae) Control
}

\author{
Denai Wahyuni ${ }^{\bowtie}$, Nila Puspita Sari, Della Lucky Hanjani \\ Program Study of Public Health Hang Tuah School of Health Pekanbaru
}

\begin{tabular}{l} 
Article Info \\
\hline Article History: \\
Submitted August 2019 \\
Accepted October 2019 \\
Published November 2019 \\
\hline Keywords: \\
Garlic extract, Blow- \\
fly larvae, Larvicide \\
\hline DOI \\
https://doi.org/10.15294/ \\
kemas.v15i2.20578
\end{tabular}

\begin{abstract}
One way to control blowflies is by using chemical pesticides; however, it causes negative effect to human, environment, and other organisms. One alternative effort is to apply garlic as insecticide and larvicide to control infestation. The study aimed to investigate the effect of garlic extract towards the mortality of blowfly's larvae and effective concentrations using LC50 and LC90. Ten blowfly larvae were used for each of these concentrations: $0.5 \%, 1 \%, 2 \%, 4 \%$, with negative control of 5 repetitions, observed every 6 hours within $2 \times 24$ hours. The Kruskal-Wallis test result showed a Sig value of $0.001<0.05$, while Spearman analysis found Sig value of $0.001<0.025$, which meant that there was a significant effect of increasing garlic extract concentration toward blowfly larvae mortality. Mann-Whitney test found Sig value of $0.001<0.05$. Probit analysis showed LC50 and LC90 values were at $2.701 \%$ and $5.498 \%$ concentrations. $4 \%$ concentration caused the most larvae mortality. It is suggested to use garlic liquid extract to control blowflies.
\end{abstract}

\section{Introduction}

Flies are one of the important vectors in the spread of disease in human, because the life of flies are inseparable from human life. In addition to being a disease-carrying vector, flies are disgusting animals for most people. This is related to its behavior in which its likes dirty places such as piles of garbage, food, and feces. Flies carry various diseasecausing microorganisms from dirty spots on food through all parts of its body that are contaminated such as its body and limb hairs, vomit, and feces (Prasetya, Yamtana and Amalia, 2015). As vectors of disease, flies can transmit various diseases such as typhus, dysentery, cholera and diarrhea (Putri, 2015). The diseases which are caused by flies have become health problems in Indonesia and also have large impact in reducing the health status and productivity of the sufferers.

Various types of flies that receive quite high attention in the health sector are house flies, meat flies, blowflies and fruit flies that can transmit various disease agents mechanically such as intestinal bacteria, worm eggs and intestinal protozoa (Ryani, Hestiningsih and Mochamad, 2017). Transmission of the disease in human can occur when a fly settles on food and transmit the bacteria that it gets from dirty breeding grounds, then the contaminated food is eaten by human. Poliomyelitis, Hepatitis, Coxsackie, Trachoma, ECHO virus infection, diarrhea, Salmonellosis, myiasis, and cholera are some of the diseases that can be transmitted by flies (Wahyuni, Makomulamin and Sari, 2017). Besides that, larva infestation also causes dangerous diseases in human, namely Myiasis. This disease is caused by seven families namely Calliphoridae, Sarcophagidae, Oestridae, Hypodermatidae, Gasterophylidae, Glossinidae, and Muscidae (Wahyudi, Soviana and Hadi 2015).

The breeding rate of flies is enormous and can reach 7-22 days in a suitable 
environment such as trash, feces and carcasses. A female fly is able to lay eggs 5-6 times with 100-150 eggs for each time, so that the density of flies will be high at landfills especially organic trash, in markets and other places that have large amounts of food. The growth rate and development of flies are influenced by the environment, temperature factors, humidity and the availability of food sources (Wahyuni, Makomulamin and Sari, 2017).

Blowfly is one type of fly that can transmit diseases and categorized as ectoparasites found in meat and carcasses of animals. It can causes tetanus and myiasis in human and animals (Sanjaya, 2008). In general, the breeding of blowflies occurs in liquid or moist place derived from rotten meat of animals (carcasses), soil containing animal waste, human waste (feces), piles of garbage, and waste disposal. It also can lay eggs on animal and human wounds (Wahyuni, Makomulamin and Sari, 2017). The existence of blowflies in certain places can disturb human life, especially in slums, garbage dump, landfills, markets, and restaurants where blowflies breed and disturb the esthetics because some people feel disgusted by their existence.

From the explanation above, it can be concluded that the fly vector, especially the blowfly, can cause several diseases that are contagious to human. It also has a high reproductive rate, therefore appropriate efforts are needed to reduce or control the population of the vector. Common method of fly vector control are physical and mechanical control, biology control and chemical control. The most commonly performed method is chemical control using synthetic insecticides. The reason for using synthetic insecticides is partly because synthetic insecticides are more effective and have lower production costs than natural insecticides.

The use of chemical insecticide can have negative impact on human, environment and other organisms. It can cause acute poisoning in human as users. It can pollute water, air and soil. It also can kill other organism such as natural enemies of pests hence caused pest resistance to pesticides. Therefore it is necessary to make an effort to get alternative insecticides and larvicides by utilizing plants that have poisonous contents to insects so that they are expected to be able to control pests effectively and environmentally friendly (Wahyuni and Yulianto, 2018).

Natural larvicides are larvicides that are made from plants that have toxic contents against insects at the larval stage. The use of larvicide is expected to have no side effects on the environment, human and does not cause resistance to insects (Nugroho, 2011). Plantbased insecticides have the same effectiveness as chemical insecticides but are easily available to the public, inexpensive and environmentally friendly (Glio, 2017). In addition, plant-based insecticides do not produce heavy residues that pose hazard, so they are easily broken down in the environment (Ellyfas, Suprobowati and Joko, 2012)

Several studies have been conducted before with objective of finding alternatives in vector control by utilizing materials contained in nature derived from plants that are safer for human and the environment, available in large quantities and easily acquired. Various types of plants can be used as important biological sources for insecticides and larvicides. In general, research on insecticides aims to determine the resistance status of the target organism, whether the insecticide is still potential within determined concentration (Wahyuningsih and Sihite, 2015). The use of insecticide and vegetable larvicide is expected to be able to suppress the insect population to the desired level, where the remaining pest population is expected to be further suppressed by natural enemies.

One of the plants that is suspected to be used as an insecticide and vegetable larvicide is garlic (Allium sativum). Garlic is very well known by the public and easily obtained. Garlic has great benefits for human life. Utilization of garlic bulbs in addition to being common to be used as a spice in the daily kitchen is also very influential in the health sector. This is evidenced from many studies on garlic as anti-microbial agent against $H$. pylori and antiparasites against Cappilaria spp (Sucipto et al., 2015). The effectiveness and mechanism of action of garlic as plant larvicides can be explained by the presence of active substances contained in them such as Allicin, Garlic oil, and Flavonoids 
(Sasmilati, Pratiwi and Saktiansyah, 2017).

Allicin substances contained in garlic can interfere with the synthesis of parasitic cell membranes. The content of essential oils (Garlic oil) in garlic is able to make larvae have difficulty taking air from the surface of the water because this substance can change the surface tension of the water where the larvae breed so that the water lacks O2. However, the phytochemical test results of garlic essential oil found other compounds namely Alkaloids, Terpenoids, and Tannins. Alkaloids act as nerve poisons for larvae, Terpenoids can inhibit appetite in larvae, and Tannin is toxic agent and can damage the larval cell membrane. Another substance from garlic that also plays role in larval death is Flavonoids. This substance can disrupt the mitochondrial respiratory system so that it can decreases oxygen use (Sumampouw, Pijoh and Wahongan, 2014)

The results of research conducted by Sasmilati, Pratiwi and Saktiansyah (2017), prove that garlic solution has the potential as a larvicide against Aedes aegypti larvae. Average larval mortality at concentrations of $10 \%, 20 \%, 30 \%$ and $40 \%$ were $56 \%, 84 \%, 94 \%$ and $100 \%$, respectively. Garlic solution has larvicidal effect on $A$. aegypti larvae with $\mathrm{LC}_{50}$ values at concentrations of $11.0453 \%$ and $\mathrm{LC}_{90}$ values at concentrations of $76.931 \%$. Research from Sulistyoningsih, Santosa and Sumanto, (2009) proved that the effectiveness of garlic solution in killing $A$. aegypti larvae from five concentrations, namely concentrations of $1 \%$, $5 \%, 10 \%, 25 \%$, and $50 \%$, found that the solution of garlic with minimun concentration of $5 \%$ could kill $A$. aegypti larvae effectively. Other study from Sumampouw, Pijoh and Wahongan (2014) concluded that garlic solutions at concentrations of $10 \%, 15 \%$, and $20 \%$ can kill Aedes spp larvae effectively because the number of larvae that die is more than $50 \%$.

Research on the effectiveness of garlic extract as a vegetable larvicide in Bowfly larvae has never been done before. This research is based on the thoughts and facts that in certain places, the presence of blowflies is very disturbing to human life, especially in slums, polling stations, landfills, markets, and restaurants where blowflies breed. Some people are disgusted by its existence but do not know how to control the fly except by using chemical insecticides. For this reason, this research is expected to be used as an additional insight to the community in safe method of fly control, namely using vegetable larvicides from plants such as garlic, which is easy to obtain. Based on the above description, we are interested in conducting research on the potential and influence of garlic extract (Allium sativum) in killing Bowfly larvae (Calliphoridae) with concentrations in the treatment group of $0.5 \%$, $1 \%, 2 \%$, and $4 \%$, as well as the control group.

This study aimed to determine the effect of garlic extract on the mortality of Bowfly larvae at various effective concentrations and the most effective concentrations based on $\mathrm{LC}_{50}$ and $\mathrm{LC}_{90}$

\section{Method}

This research was conducted at the Integrated Laboratory of Chemistry Study Program at the Muhammadiyah University of Riau, Pekanbaru in April to June 2018. The test insects in this study were Bowfly larvae that were bred. The garlic used in this test was obtained from Arengka Morning Market in Pekanbaru City.

This study examined the effectiveness of garlic extract as a plant-based insecticide on Bowfly larvae wihout ignoring factors that affect the life of blowflies, namely the temperature and humidity of the air and the available food (Wahyuni, Makomulamin and Sari, 2017). This study used a Completely Randomized Design Method (CRD) with four concentrations of $0.5 \%, 1 \%, 2 \%$ and $4 \%$, with negative control of distilled water and five times repetition.

Preparation of test animals was performed by breeding fly eggs. Blowflies were invited by placing pieces of dead fish that have high protein content in a bowl, then it was placed in an open space. Eggs in culture media would hatch into larvae. Furthermore, the larvae are maintained and are waited for about 4-5 days to become the third instar for the test object. The test sample for each concentration and negative control consisted of 10 larvae with 5 repetitions so that the total sample was 250 Bowfly larvae. 


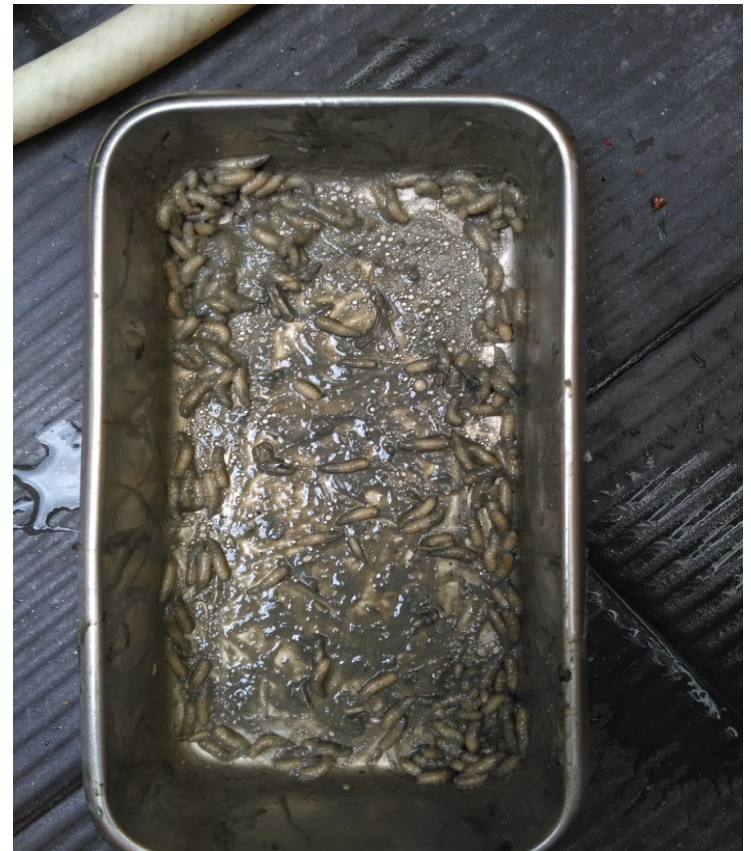

Figure 1. Breeding of Bowfly larvae into instar larvae III

Garlic extract was made using two methods, namely maceration and extraction methods. Two kg was cleaned using clean water and then it was finely chopped. After chopping, the garlic was dried at room temperature and was protected from direct sunlight, then blended. On mashed garlic powder, maceration was done by soaking with $96 \%$ ethanol solution. Garlic powder was soaked (macerated) until perfectly submerged for $3 \times 24$ hours. After 3 $\mathrm{x} 24$ hours, the solution was filtered with filter paper using a Buchner funnel and cotton and then it was placed in a dark bottle. The pulp from the first filtering result was soaked again for $1 \times 24$ hours and then filtered and the same thing was done on the second and third immersion. The next step was extraction of macerated garlic solution using an equipment called Vacuum Rotary Evaporator to produce a concentrated brown extract. The extract was stored in a refrigerator until usage.

In order to get a concentration of $0.5 \%$, $0.05 \mathrm{ml}$ garlic extract was added with $9.95 \mathrm{ml}$ aquadest to obtain a total solution of $10 \mathrm{ml}$. Similar methods were done for concentrations of $1 \%, 2 \%$ and $4 \%$. The solutions were put into test glasses before Bowfly larvae were added.

The test was carried out by inserting 10
Bowfly larvae using tweezers into test glasses that were filled with various concentrations of garlic extract solution and on negative control. The process were repeated five times. The behavior of the Bowfly larvae was observed during test by observing the motion and physical condition of the larvae. Bowfly larva was declared dead if it did not move anymore when it was touched with a spatula. In addition, room temperature was also recorded because it could affect the proliferation of larvae. Observations were carried out every 6 hours for $2 \times 24$ hours. Long time observation of garlic insecticide exposure was carried out at one concentration of extract that was most effective in killing Bowfly larvae. It was intended to see how long the average time needed to kill the whole test larvae.

Data analysis was conducted using statistical analysis of variance with CRD followed by one way ANOVA test. After the data were processed, it turned out that one way ANOVA test could not be carried out because it did not meet the requirements, therefore alternative test was carried out using Non Parametric Kruskal-Wallis Test and Spearman Analysis test in order to determine the degree of relationship between independent variables and dependent variables. Probit Analysis was then performed to determine the effectiveness of garlic extract on mortality at various effective concentrations and the most effective concentration based on $\mathrm{LC}_{50}$ and $\mathrm{LC}_{90}$.

\section{Results and Discussions}

The death process of Bowfly larvae at each concentration varies in terms of time of death, number of deaths, and behavior of larvae during immersion. Based from the behavior of larvae when they first entered into the test solution with the lowest concentration of $0.5 \%$ and $1 \%$, it appeared that the larvae were not affected by the test solution because there were no active movements. However, different conditions were seen at concentration of $2 \%$ and $4 \%$ where the larvae moved actively, were agitated and always tried to move out and spread from the test glass. The death process of larvae could also be seen from the duration of exposure. Average time of death of larvae started at 18 hours of immersion, but at concentration of $4 \%$ dead larvae could be found at a faster 
immersion time, namely at 6 hours immersion. This proved that higher extract concentration could cause higher number of larval death and quicker death time compared to lower extract concentration.

Larvae that were long exposed before dying had different behavior compared to initial immersion time. In innitial immersion time, the larvae were first quite active. However, prolonged exposure to extract solution caused the larvae to be less active when they were touched. There were no more larvae that climb the test glass at concentrations of $2 \%$ and $4 \%$. The observation of the percentage of mortality of Bowfly larvae every 6 hours for 48 hours can be seen in Figure 2 below.

Figure 2 above shows that in the treatment group with concentration of $0.5 \%$, when Bowfly larvae were immersed in garlic extract, they were seen not actively moving to find a way out. The process of death lasted quite a long time and after 48 hours of observation, the number of death Bowfly larvae was only 10 larvae (20\%). At concentration of $1 \%$ garlic extract, the behavior and condition of the Bowfly larvae were almost the same as the concentration of $0.5 \%$, where the movement of the larvae was not so active. Larvae mortality was found not too much, almost equal to concentration of $0.5 \%$ with total of 14 death Bowfly larvae (28\%). At concentration of $2 \%$, Bowfly larvae had restless activities during immersion to garlic extract and some larvae tried to climb the test glass to find a way out. The process of death took place rather quick, because in 12 hours of immersion, there were already dead larvae. The number of larval mortality at concentration of $2 \%$ after 48 hours of observation was 18 larvae (36\%). At concentration of $4 \%$, the larvae appeared to be restless during immersion. The larvae often climbed the test glass to avoid being submerged in the test solution. The process of death takes place rather quick that at 6 hours immersion there were already dead larvae. The total number of larvae that died at this concentration was more than the other concentrations, amounting to 38 larvae (76\%). Negative control did not cause larval death at all in all repetitions.

Environmental temperature was one of the causes that made larvae could survive even though immersion had been carried out. The test was carried out at ambient temperature. From the results of observations, the average temperature of the environment when doing garlic extract testing on Bowfly larvae was $28^{\circ} \mathrm{C}$.

From statistical analysis, Non Parametric Kruskal Wallis test obtained Sig value of $0.001<0.05$. This value meant that there were significant differences in larval mortality between the treatment groups with different mean rank values. Spearman test was conducted to see whether there was a correlation between treatment and the death of blowfly larvae.

The results of NonParametric Sperman correlation test obtained Sig (2-tailed) value of $0.001<0.025$ which meant that there was a significant correlation between increased concentration of garlic extract on the number of blowfly larvae mortality. The

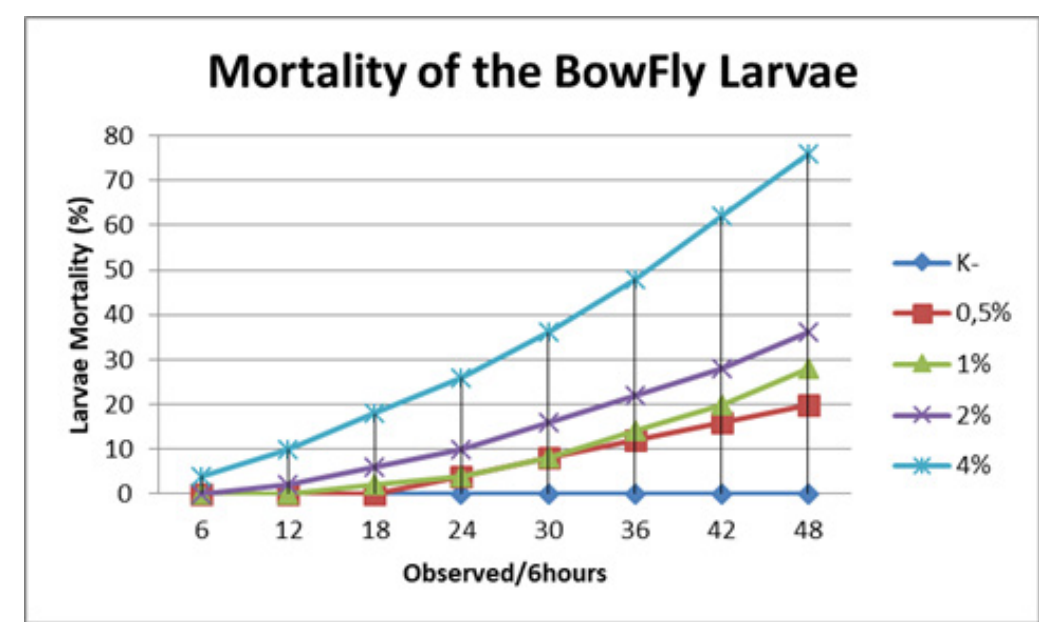

Figure 2. Percentage Mortality of Bowfly Larvae 
Table 1. The results of LC50 and LC90 tests of garlic extract on mortality of blowfly larvae

\begin{tabular}{lllll}
\hline \multirow{2}{*}{ No. } & \multirow{2}{*}{ Point } & Exposure & \multicolumn{2}{c}{ 95\% Confidence Limits } \\
\cline { 4 - 5 } & & Concentration (\%) & Lower Bound & Upper Bound \\
\hline 1 & LC $_{50}$ & 2.701 & 0.300 & 2.399 \\
2 & LC $_{90}$ & 5.498 & 0.536 & 32.582 \\
\hline
\end{tabular}

Source: Primary Data

strength of correlation was denoted by strong interpretation with a value of 0.727 . In this case, it could be interpreted that the higher the concentration of the solution, the number of larval deaths would also increase.

Mann-Whitney test was carried out to see which group had the real differences that influence the mortality of larvae. In this test, the value of Sig between control group and various concentrations were as follows: control group and concentration $0.5 \%$ had $\mathrm{p}$ value of 0.038; control group and concentration of $1 \%$ had $\mathrm{p}$ value of 0.015 ; control group and concentration of $2 \%$ had $\mathrm{p}$ value of 0.002 ; control group and the concentration of $4 \%$ had $\mathrm{p}$ value of 0.001 ; concentration $2 \%$ group and concentration $4 \%$ group had $\mathrm{p}$ value of 0.021 . From these results, it could be concluded that the groups that had very significant differences that affect larval mortality were control group and $4 \%$ concentration with Sig of $0.001<0.05$.

On Probit Analysis, according to 2015 WHO parameters of larvicide effectivity, concentration of larvicides is considered effective if it can cause larval mortality between $10-95 \%$ of test that will be used to determine the value of Lethal Concentration (LC). Based on Table 1 above, the results of calculations using Probit Analysis Method obtained LC50 values of $2.701 \%$ and LC90 values of 5.498\%.

The results of Kruskal-Wallis nonparametric test found $\mathrm{P}$ value of $0.001<0.05$. This value meant that there were significant differences of larval mortality between treatment groups with different average values using immersion time of 48 hours. This was shown by observations of death process on various concentrations of treatment. It appeared that an increase in larval mortality occurred with increased concentration of garlic extract. Susanto et al. (2011) explained the possibilities that could affect the number of dead larvae at each concentration were due to differences in the sensitivity of each larvae to the extract concentration.

Similar conclusion with different results was also obtained in the study by Sasmilati, Pratiwi and Saktiansyah (2017) with the title «Effectiveness of white onion solution (Allium sativum) as larvicide against Aedes aegypti larvae". This study found that at concentration of $10 \%$, the number of dead larvae was 14 , while at concentration of $40 \%$, all of test larvae were dead. In addition, a study conducted by Sumampouw, Pijoh and Wahongan (2014) with the title "Effect of white onion solution (Allium sativum) on Aedes spp larva" showed that extract concentration of $1 \%$ could only kill $20 \%$ of the larvae, whereas at extract concentration of $20 \%$ could cause $100 \%$ larval death.

The effect of insecticide to kill insects in the extract immersion method is very dependent on its form, the way it enters insect body, the type of substance contained, the dose concentration, and the duration of exposure (Rahmayanti, Putri and Fajarna, 2016). In Figure 2, it could be seen that 6 hours immersion in concentration of $4 \%$ could kill 2 blowfly larvae and in 48 hours immersion, the death was $76 \%$. This number is the highest and fastest death rate compared to other concentrations. This study is in line with a research conducted by Sumampouw, Pijoh and Wahongan (2014) which examined the effect of garlic solution on Aedes spp larvae and found that concentration of $20 \%$ could kill $100 \%$ of test larvae within 24 hours immersion.

Other things to consider during testing process was the environment 
temperature because one of the causes that made larvae could survive the immersion process was environmental temperature. From the observations, the average temperature of the testing place during tests was $28{ }^{\circ} \mathrm{C}$. In this study, the temperature greatly affected the death of blowfly larvae because the temperature of $28{ }^{\circ} \mathrm{C}$ was below normal temperature for fly development. In a study by Wahyuni, Makomulamin and Sari (2017), it was also explained that the larvae were wandering around to look for a place with preferrable temperatures of $30-35{ }^{\circ} \mathrm{C}$. In this case, it could be concluded that the larvae would experience developmental disorders if they were grown at temperatures below $30^{\circ} \mathrm{C}$ or above $35{ }^{\circ} \mathrm{C}$.

The death mechanism of blowfly larvae in this study was influenced by compounds which were contained in garlic extract in the form of allicin, flavonoids, and garlic oil that enter the body of larvae through the body surface (contact poison), respiratory system (respiratory poison), and through the mouth and digestive tract (stomach poison). This was in lini with a study by Kristiana, Ratnasari and Haryono (2015) which found that the level of larvicidal toxicity to kill larvae was very dependent on the form of larvicides, how the compounds enter into the larval body, larval body size and composition, and larval stage and habitat. Larvicides enter the body of larvae through three ways, namely the surface of the body, the mouth and digestive tract, and the respiratory system.

Based on observations, during garlic extract immersion, blowfly larvae shown restless activities and some larvae tried to climb the test glass to find a way out. Blowfly larvae death was caused by Allicin compound contained in garlic extract. This compound enter the body of blowfly larvae through digestive organs and then was absorbed by the body and disrupt the larval nervous system. This is in line with a research conducted by Rusdy (2010) which stated that Allicin is a derivative of sulfides which are stomach poisons. Stomach poison is a poison that can kill the target organism if it enters the digestive organs and is absorbed by the intestinal wall. Furthermore, the compounds were carried by bodily fluids (hemolymph) to the most sensitive and deadly target sites in the nervous system.

In garlic plants, allicin compound was obtained after the cutting process. This was in line with a research conducted by Febyan et al. (2015) which found that in order to get allicin compound, the garlic must be mashed or cut first. Cutting or breaking garlic causes the $\mathrm{t}$ allin to allicin. Allicin compound contained in garlic could inhibit the development of stage 3 larvae so that the larvae would not turn into pupae and eventually die because the cell membrane has been damaged.

Besides allicin, other compounds in garlic which could cause larval mortality was Flavonoid. Flavonoids is pungent and water soluble (Karlina, Ibrahim and Trimulyono, 2013). A study by Yunikawati, Besung. INK and Mahatmi. H (2013) found that flavonoids are one of the largest groups of natural phenols that have a tendency to bind to proteins so that they disrupt the metabolic processes that cause death in insects. Another study by Lumbessy, Abidjulu and Paendong (2013) found that a number of medicinal plants which contained flavonoids had been reported to have antioxidant, anti-viral, anti-inflammatory, antiallergic, and anti-bacterial properties. Utami and Cahyati (2017) stated that flavonoids is cholinesterases. Anticholinesterase causes the cholinesterase enzyme to phosphorylate and become inactive. With the inactivity of the cholinesterase enzyme, there will be an obstacle in the process of degradation of acetylcholine, resulting in the accumulation of acetylcholine in the synapse gap. Furthermore there is an increase in excitatory transmission, which causes the respiratory muscles to contract continuously, resulting in respiratory muscle spasms and cause death

The effects of flavonoids on the death of blowfly larvae in this study were as respiratory poisons and contact poisons in which if they were absorbed and entered the body cavity excessively there would be an inhibition of larval metabolism which eventually led to death. This was in line with a research by Wahyuni and Yulianto (2018) about basil leaves 
for controlling Aedes aegipty mosquito by spraying. The flavonoid content of the extract was bioactive compound which if they enter the body through the mouth, respiratory tract, and through spiracles that are found on the surface of the skin could cause nerve disorders that could cause the body to be flaccid and eventually caused death. A study conducted by Barbie, Istiana and Wydiamala (2017) explained that flavonoid compound enter the larval body through the respiratory system and could cause nerves flacidity and damages to the respiratory system and also made the larvae could not breathe and eventually die. Furthermore, flavonoid compounds as contact poisons caused the larvae body to shrink. This was in line with the results of a research by Cania and Setyaningrum (2013) which found that the change in body of larvae from normal conditions was caused by flavonoid compounds because it could cause weakness in larval nerves. Another study by Gautam, Kumar and Poonia (2013) using larvae of Anopheles and A. aegypti that given extracts of the plant Vitex negundo contained flavonoids showed disintegration of integument associated with loss of chitin layer and abnormal stretching of the larval body.

Other content of garlic that could play roles in the death of the larvae was garlic oil. The role of garlic oil in this study was very influential on the death of blowfly larvae because it acted as an inhibitor of oxygen in the larvae. According to Sumampouw, Pijoh and Wahongan (2014) garlic oil compounds worked by changing the surface tension of the water so that the larvae had difficulty taking air from the surface of the water. This made the larvae did not get enough oxygen for their growth and caused the death of larvae. In addition, garlic oil also had other secondary metabolite compounds that affect the death of blowfly larvae. This had been proven from the phytochemical test results of garlic oil conducted by Sasmilati, Pratiwi and Saktiansyah (2017) which showed that garlic oil contained secondary metabolites in the form of terpenoids, alkaloids, and tannins.

Based on observation, the larvae also probably lost their appetite because of terpenoid compunds. Terpenoid is a compound that has bitter taste that made the larvae did not want to eat. This was consistent with the explanationbySasmilati,PratiwiandSaktiansyah (2017) which found that terpenoids were compounds that act as inhibitors of appetite in larvae because these terpenoids have a bitter and sharp taste that made the larvae could not be able to eat, therefore that they would starve and eventually died. Beside that, terpenoids and alkaloids could also affect the work of insect's respiratory and nervous system. In general, these compounds could enter the body of insects through the respiratory tract, namely through spiracles and pores on the surface of the body. It could attack the central nervous system and quickly causes paralysis (Husna, Priyono and Darwi, 2012).

Based on observation in this study, larvae which had been exposed to the extract in long time experienced a change in behavior from active movements to become sluggish, unmoved, and eventually died. The dead larvae would present in the base of the solution and their color would become pale. This was explained in a study by Cania and Setyaningrum (2013) which stated that alkaloid compounds acted as stomach poisons and nerve poisons in larvae. Alkaloids is present in the form of salt, therefore they could degrade the cell membranes to enter and damage the cells and could also disrupt the works of the larval nerve system by inhibiting the action of acetylcholinesterase enzyme. Alkaline compunds caused color changes in the body of the larvae which became more transparent and slowing down of body movements and bending of the body when the larvae were stimulated by touch. Another study by Yunikawati, Besung. INK and Mahatmi. $\mathrm{H}$ (2013) found that alkaloids could interfere with the peptidoglycan components in bacterial cells, therefore the cell wall layer was not formed intact and caused cell death.

Tannin also has influence on the shrinkage of larvae body. This was proved in the results of research observations that showed the larvae body to shrink. The observation of this study was in line with a study by Arlofa (2016) which explained the mechanism of action of tannin to shrink cell walls or cell membranes through interference in cell permeability which made the cells did not able to perform life activities, therefore their growth was inhibited 
and they would be dead. Tannin could reduce the intensity of eating that resulted in disruption of insect growth (Lestari, Mukarliana and Yanti, 2014). Another study by Yunita, Suprapti and Hidayat (2009) found that tannin compounds also interfered with the digestive system of larvae in the absorption of food which caused larvae body to be smaller and thinner. In a study by Wahyu et al. (2018), Tannin also found to affect the mortality of $A$. aegypti larvae because it also disrupts the digestive system of larvae in the absorption of food which results in the body becoming increasingly smaller and thinner. Sumilih, Ambarwati and Astuti (2010) explained that tannin generally inhibits enzyme activity by forming complex bonds with proteins on enzymes and substrates that can cause digestive disorders and can damage the cell walls in insects, so that the mechanism of action of tannins is also a stomach poison.

Furthermore, this study calculates LC50 and LC90 values which were intended to measure the killing power of garlic extract against blowfly larvae. Based on the results of calculations using Probit Analysis Method in the SPSS application at all concentrations, the LC50 value was $2.701 \%$ which meant that the concentration of $2.701 \%$ was effective in killing $50 \%$ of the blowfly larvae. Meanwhile, the LC90 was $5.498 \%$ which meant that the concentration of $5.498 \%$ could kill $90 \%$ of blowfly larvae. From these results, it could be concluded that at $4 \%$ concentration was effective in killing $50 \%$ of blowfly larvae because from 50 larvae, 38 larvae were killed.

The LC50 and LC90 values in this study were lower than the results of studies conducted by Sasmilati, Pratiwi and Saktiansyah (2017) which used garlic extract on Aedes aegypti larvae and found LC50 values of $11.0453 \%$ and LC90 values of $76.931 \%$. Another study by Yusmira and Istianah (2015) with $70 \%$ ethanol extract of garlic treatment against Ascaridia galli worms obtained LC50 values of $26.852 \%$ and LC90 of $65.85 \%$.

Based on the results of the study, it could be seen that garlic extract could potentially became a larvicide because garlic contains compounds that played important roles in killing blowfly larvae. Garlic extract also served as repellent in the presence of insects and was effective in controlling pests. Garlic is widely found and is very easy to get everywhere. Sri Utami (2010) explained that things to consider in the use of plants that have the potential as plant-based insecticides are as follows: 1). Easy to get in nature and everywhere, 2). The biomass can be obtained in abundance, 3). Easily decomposes in the environment so it does not pollute the environment and is safe for human and animals.

Four percent concentration was selected as the most effective concentration and had potential as larvicides in controlling blowfly. At that concentration, it could kill more than $50 \%$ of fly larvae and also could cause larval death in a short time (6 hours). It can be concluded that the bioactive substances contained by garlic extract have the potential as plant larvicides against blowflies.

\section{Conclusions}

Based on the results of this study, Spearman analysis obtained Sig value (2-tailed) of $0.001<0.025$ ), which meant that higher concentration of garlic extract could increase larvae mortality. This meant that there was a significant relationship between increased concentration of garlic extract and blowfly larvae mortality, with a strong interpretation with a value of 0.727 . Mann Whitney test obtained Sig value of $0.001<0.05$, groups that had the most significant differences in term of larvae mortality was between control group and $4 \%$ concentration group. Based from Probit Analysis, garlic extract has larvicidal effect on blowfly larvae with LC50 values at concentration of $2.701 \%$ and LC90 values at concentration of $5.498 \%$. The $4 \%$ concentration is the most influential concentration on the mortality of blowfly larvae.

\section{References}

Arlofa, N., 2016. Uji Kandungan Senyawa Fitokimia Kulit Durian sebagai Bahan Aktif Pembuatan Sabun, Jurnal Chemtech, 1(01), pp. 18-22.

Cania, E., \& Setyaningrum, E., 2013. Uji Efektifitas Larvasida Ekstrak Daun Legundi (Vitex trifolia) Tterhadap Larva Aedes aegypti, Medical Journal of Lampung University, 2(4), pp. 52-60.

Ellyfas, K., Suprobowati, O.D., \& Joko, S.C.B.U., 2012. Pengaruh Pemberian Ekstrak Buah 
Nanas (Ananas comosus L. Merr) Terhadap Kematian Larva Aedes aegypti. Jurnal Analis Kesehatan, 1(2), pp. 62-67.

Febyan, F. Wijaya, S.H., Adinata, J., Hudyono, J., 2015. Peranan Allicin dari Ekstrak Bawang Putih Sebagai Pengobatan Komplemen Alternatif Hipertensi Stadium I. CDK-227, 42(4), pp. 303-6.

Gautam, K., Kumar, P., \& Poonia, S., 2013. Larvicidal Activity and GC-MS Analysis of Flavonoids of Vitex negundo and Andrographis paniculata Against two Vector Mosquitoes Anopheles stephensi and Aedes aegypti. Journal of Vektor Borne Diases, 50, pp. 171-178.

Glio, M.T., 2017. Membuat Pestisida Nabati untuk Hidroponik, Akuaponik, Vertikultur, \& Sayuran Organik. Jakarta: PT AgroMedia Pustaka.

Husna, S., Priyono, B., \& Darwi, A., 2012. Efikasi Ekstrak Daun Lengkuas Terhadap Mortalitas Larva Nyamuk Anopheles aconitus, Unnes J Life Sci, 1(1), pp. 41-6. Karlina, C., Ibrahim, M., \& Trimulyono, G., 2013. Aktivitas Antibakteri Ekstrak Herba Krokot (Portulaca oleracea L.) terhadap Staphylococcus aureus dan Escherichia coliNo Title, Lentera Bio, 2(1), pp. 87-93.

Kristiana, I.D., Ratnasari, E., \& Haryono, T., 2015. Pengaruh Ekstrak Daun Bintaro (Cerbera odollam ) terhadap Mortalitas Larva Nyamuk Aedes aegypti. Lentera Bio, 4(2), pp. 131-135.

Lestari, M.A., Mukarliana., \&Yanti, A.H., 2014. Uji Aktivitas Ekstrak Metanol dan n-Heksan Daun Buas-Buas (Premna serratifolia Linn.) pada Larva Nyamuk Demam Berdarah (Aedes aegypti). Jurnal Protobiont, 3(2), pp. 247-251.

Lumbessy, M., Abidjulu, J., \& Paendong, J.J.E., 2013. Uji Total Flavonoid Pada Beberapa Tanaman Obat Tradisonal Di Desa Waitina Kecamatan Mangoli Timur Kabupaten Kepulauan Sula Provinsi Maluku Utara. Jurnal MIPA, 2(1).

Nadila, I., Istiana, I., \& Wydiamala, E., 2017. Aktifitas Larvasida Ekstrak Etanol Daun Binjai (Mangifera caesia) Terhadap Larva Aedes aegypti. Berkala Kedokteran, 13(1),

Nugroho, A.D., 2011. Kematian Larva Aedes aegypti Setelah Pemberian Abate Dibandingkan Dengan Pemberian Serbuk Serai. Jurnal Kesehatan Masyarakat, KEMAS, 7(1), pp. 91-96.

Prasetya, R.D., Yamtana., \& Amalia, R., 2015. Pengaruh Variasi Warna Lampu pada Alat Perekat Lalat Terhadap Jumlah Lalat Rumah (Musca domestica) yang Terperangkap.
Jurnal Balaba, 11(1), pp. 29-34.

Putri, Y.P., 2015. Keanekaragaman Spesies Lalat (Diptera) Dan Bakteri Pada Tubuh Lalat di Tempat Pembuanagan Akhir Sampah (TPA) Dan Pasar, Jurnal Dampak, 12(2), pp. 79-89.

Rahmayanti, R., Putri, S., \& Fajarna, F., 2016.Uji Potensi Kulit Bawang Bombay (Allium cepa) Sebagai Larvasida Terhadap Kematian Larva Nyamuk Aedes aegypti.JESBIO, 5(1), pp. 18-22.

Rusdy, A., 2010. Pengaruh Pemberian Ekstrak Bawang Putih Terhadap Mortalitas Keong Mas. Jurnal Floratek, 5(2), pp. 172-180.

Ryani, H., Hestiningsih, R., \& Mochamad, H., 2017. Ektoparasit (Protozoa Dan Helminthes) Pada Lalat Di Pasar Johar Dan Pasar Peterongan Kota Semarang. Jurnal Kesehatan Masyarakat (e-Journal), 5(4), pp. 570-576.

Sanjaya, Y., 2008. Pengujian Feromon Seks pada Lalat Hijau Lucillia sericata Meigen (Diptera: Calliphoride). Jurnal Bionatura Universitas Pendidikan Indonesia, 10, pp. 49-57.

Sasmilati, U., Pratiwi, A.D., \& Saktiansyah, L.O.A., 2017. Efektivitas Larutan Bawang Putih (Allium sativum Linn) Sebagai Larvasida Terhadap Kematian Larva Aedes aegypti di Kota Kendari Tahun 2016. Jurnal Ilmiah Mahasiswa Kesehatan Masyarakat, 2(6), pp. $1-7$.

Sri-Utami., 2010. Aktifitas Insektisida Bintaro (Carbera odollam Gaertn) Terhadap Hama Eurema spp. Pada Skala Laboratorium. Jurnal Penelitian Hutan Tanaman, 7(4), pp. 211-220.

Sucipto, M.P.G., Setyaningrum, E., Carolia, N., Kurniawan, B., 2015. Influece Of Garlic (Allium sativum L.) Extract as The Larvicide Of Aedes aegypti Larva, Jurnal Majority, 4(2), pp. 45-51.

Sulistyoningsih, D., Santosa, B., \& Sumanto, D., 2009. Efektivitas Larutan Bawang Putih dalam Membunuh Larva Aedes aegypti. Jurnal Kesehatan, 2, pp. 38-44.

Sumampouw, S.P.M., Pijoh, V.D., \& Wahongan, G.J.P., 2014. Pengaruh Larutan Bawang Putih (Allium sativum) Pada Larva Aedes spp di Kecamatan Malalayang Kota Manado. Jurnal e-Biomedik, 2(2), pp. 436-441.

Sumilih, S., Ambarwati, A., \& Astuti, D., 2010. Efektifitas Ekstrak Lempuyang Wangi (Zingiber aromaticum Val.) Dalam Membunuh Larva Aedes aegypti. Jurnal Kesehatan, 3(1), pp. 78-88.

Susanto, I.Ismid, I.S., Sjarifuddin, P.K., 2011. Buku Ajar Parasitologi Kedokteran. Edisi 4. Jakarta: FK UI. 
Utami, I., \& Cahyati, W.H., 2017. Potensi Ekstrak Daun Kamboja Sebagai Insektisida Terhadap Nyamuk Aedes aegypti. Higeia, 1(1), pp. 2228.

Wahyudi, P., Soviana, S., \& Hadi, U., 2015. Keragaman Jenis dan Prevalensi Lalat Pasar Tradisional di Kota Bogor (Diversity and Prevalence Of Flies At Traditional Markets In Bogor City). Jurnal Veteriner, 16(4), pp. 474-482.

Wahyuni, D., Jasril, J., Makomulamin, M., Sari, N.P., 2018. Carbera manghas Leaf Extract as Larvicide in Controlling Aedes aegypti. Proceeding International Conference. CELSciTech. Pekanbaru: Universitas Muhammadiyah Riau., 3, pp. 93-101.

Wahyuni, D., Makomulamin, M., \& Sari, N.P., 2017. Entomologi dan Pengendalian Vektor. Yogyakarta: Deepublish.

Wahyuni, D., \& Yulianto, B., 2018. Basil leaf (Ocimmum basillum form citratum) Extract Spray in Controling Aedes aegepty. Jurnal Kesehatan Masyarakat (KEMAS), 14(2), pp.
147-156.

Wahyuningsih, N., \& Sihite, R., 2015. Perbedaan respon Aedes aegypti (Linnaeus) (Diptera: Culicidae), terhadap paparan anti nyamuk bakar dan bunga keluwih (Artocarpus camansi, Blanco). Jurnal Entomologi Indonesia, 12(1), pp. 20-30.

Yunikawati, M.P.A., Besung. I.N.K., \& Mahatmi. H, 2013. Efektifitas Perasan Daun Srikaya Terhadap Daya Hambat Pertumbuhan Escherichia coli. Jurnal Indonesia Medicus Veterinus, 2(2), pp. 170-9.

Yunita, E.A., Suprapti, N.H., \& Hidayat, J.W., 2009. Pengaruh Ekstrak Daun Teklan (Eupatorium riparium) Terhadap Mortalitas dan Perkembangan Larva Aedes aegypti. Jurnal Bioma, 11(1), pp. 11-17.

Yusmira, G., \& Istianah, S., 2015. Uji Daya Atihelmintik Ekstrak Etanol 70 \% Bawang Putih (Allium sativum L.) Terhadap Cacing Ascaridia galli In vitro. Biomedika, 7(1), pp. 11-14. 